\title{
THE ALL-HAPPY GOD
}

\author{
Joseph Stenberg
}

\begin{abstract}
Is God happy? In the tradition of classical theism, the answer has long been "Yes." And, just as God is not merely powerful, but all-powerful, so too God is not merely happy, but all-happy or infinitely happy. Far from being empty praise, God's happiness does important work, in particular, in explaining both human existence and human destiny. This essay is an attempt to give divine happiness the serious philosophical treatment it deserves. It turns out that, as with many divine traits, ascribing all-happiness to God is not without potential problems. I raise and attempt to address what I take to be the most serious problem, which I call "The Subjective Problem of Evil."
\end{abstract}

Is God happy? In an age in which "happiness" has become associated almost entirely with feeling good, it may seem odd or even incoherent to describe God as "happy." ${ }^{1}$ However, in the tradition of classical theism, the answer has long been "Yes." ${ }^{2}$ And, just as God is not merely powerful, but all-powerful, so too God is not merely happy, but happy in an especially elevated way. This commitment is expressed, for example, in Thomas Aquinas's work: "Divine happiness infinitely exceeds that of humans." 3 All-happy, indeed! In recent years, philosophers have paid a great deal of attention to some classical divine attributes, such as simplicity and omnipotence. ${ }^{4}$ But, although it was clearly of importance to prominent classical thinkers, divine happiness has not been among the attributes given a serious philosophical treatment.

${ }^{1}$ One might think that it is incoherent if one believes that the feelings in question essentially involve having a body.

${ }^{2}$ For this claim in the tradition of classical theism, see, e.g., Anselm, Proslogion, ch. 5, and Aquinas, Summa Contra Gentiles I 102, 6.

${ }^{3}$ Aquinas, Summa Contra Gentiles I 102, 6. See also, Aquinas, Summa Theologiae Ia 26, 1: "happiness maximally belongs to God;" and Summa Contra Gentiles, I 102: "[God] is singularly perfectly happy," "God is incomparably happy above all things," "human happiness is altogether incomparable, particularly [the happiness] of this life, to divine happiness."

${ }^{4}$ For recent discussions of divine simplicity, see, e.g., Bergmann and Brower, "A Theistic Argument against Platonism," 357-386; Mullins, "Simply Impossible," 181-203; and Yandell, "How Many Times Does Three Go Into One," 151-169. For recent discussions of omnipotence, see, e.g., Flint and Freddoso, "Maximal Power," 81-113; Wierenga, The Nature of God; and Morriston, "Omnipotence and Necessary Moral Perfection," 143-160. 
One might think there is good reason for this. Perhaps the explanation is that God's being called "happy" is vacuous in the tradition-a kind of honorific title that doesn't do any real work and so isn't of any real interest. But that just isn't so. God's happiness is called upon at crucial moments to help explain fundamental theological doctrines. For example, in the classical Christian tradition, it is called upon to help explain why God created human beings in the first place: God wanted to share God's happiness with others. ${ }^{5}$ So divine happiness has traditionally held a sort of pride of place, since it plays a role in explaining both human existence and human destiny (for the fortunate, anyway). And precisely because God is supposed to have wanted to share God's happiness with others, in the classical theistic tradition, God's happiness is often treated as a model for the outer reaches of the sort of happiness that we might obtain with God's help. Spending time delving into what God's happiness amounts to, then, might also give us insight into what the best conceivable sort of human happiness involves. So God's happiness is worthy of serious reflection. ${ }^{6}$

The starting point of this paper, however, is not God's happiness itself, but rather popular accounts concerning the general nature of happiness. I begin with the general nature of happiness because it seems like a natural starting point, just as, for example, it seems that an account of the general nature of power is the natural starting point for an analysis of omnipotence. I show that, in principle, a variety of popular accounts concerning the nature of happiness could account for God's infinite or all-happiness. This is so despite the fact that many of the traits associated with God on the classical theistic picture strain against how we ordinarily think about happiness, including God's immateriality, metaphysical simplicity, immutability, and eternality. Next, I argue that, no matter which of these popular general accounts we prefer, sense too can be made of the key traditional claim that God's happiness can, in some sense, be shared with human beings.

Supposing the argument can be plausibly advanced that far, a problem remains that is much like a problem familiar from other contexts. For even if we can make sense of God's happiness, one might still question ascribing all-happiness to God, on the grounds that a God that is all-good could not be all-happy when there is evil in the world. It seems that either God could be all-happy and callous towards the suffering of others (and so not all-good), or God could be all-good and fall short of all-happiness

${ }^{5}$ This is an old belief-see, e.g., Aquinas's De Malo 5, 3. That tradition endures today, for example, in the Catechism of the Catholic Church, paragraph 1: "God, infinitely perfect and blessed (beatus) in himself, in a plan of sheer goodness freely created man to make him share in his own blessed life."

${ }^{6}$ I have avoided motivating concern for God's happiness by appealing to perfect being theology because, as will become clear, I do not think that happiness has an intrinsic maximum and so it is not clear whether it counts as a perfection in the sense relevant to perfect-being theology. 
because of the plight of God's creatures. In short, in a world that includes evil, it seems that God can't both be all-happy and all-good. And, since perfect goodness certainly seems to be a more central divine attribute than all-happiness, one might think that we ought to reject the idea that God is all-happy. Notice that this problem, though similar, is independent of the usual Problem of Evil, since what is at issue here is, as it were, God's subjective response to a world that includes evil, rather than God's objective, (in)active response to various evils. Even if there were a morally sufficient reason for God's allowance of each and every evil that occurs, this problem, what I will call the "Subjective Problem of Evil," would still arise.

The essay is organized into three main sections. In Section 1, I show that, when taken in conjunction with other attributes classically ascribed to God, God turns out to be all-happy or infinitely happy on an array of popular views concerning the general nature of happiness. In Section 2, I argue that God's happiness can be shared with human beings on all of the popular views concerning happiness's general nature that I consider. And, in Section 3, I attempt to make headway in addressing the Subjective Problem of Evil.

\section{Popular Accounts of Happiness and the Case of God}

In talking about happiness today, caution is required. There are at least two currently lively bodies of literature on happiness. ${ }^{7}$ The first uses the word "happiness" in a descriptive sense to refer to a psychological state or condition connected to positive affect or some particular element(s) involved in positive affect, such as experiencing pleasure or being in a good mood. The second uses the word "happiness" as roughly a synonym for well-being and takes happiness to have significant evaluative or normative force. ${ }^{8}$ What happiness in the first sense has to do with happiness in the second sense, if anything, is an open question. For the purposes of this paper, I am only interested in happiness in the second sense, as connected to well-being, and so all the claims about happiness that follow should be taken in that sense.

That in itself may do something to alleviate the worry that it is nonsense to talk about God's happiness, since one might rightly regard it as nonsense on the classical picture of God to claim that God is in a good mood. ${ }^{9}$ But some may counsel us to be cautious for another more general reason, if we insist on speaking in this way. In particular, some may suggest that language works differently as applied to God and so we must not think that we are claiming one and the same thing when we say "I am happy" and "God is happy." Here I merely flag the difference between these perhaps rightly cautious souls who think that, in ascribing perfective

\footnotetext{
7See, e.g., Haybron, The Pursuit of Unhappiness, 5-6.

${ }^{8}$ I say "roughly" because I tend to think that "happy" in this second sense refers only to those in a special class of those with a positive level of well-being.

${ }^{9}$ In the Christian tradition, complications stemming from Jesus aside.
} 
attributes to God, we use the relevant terms only analogically and those who are bold to claim that we use such terms univocally. Of course, in many respects, a great deal hangs on the difference. However, in thinking about all-happiness as opposed to, say, omnipotence or omniscience, no special issues arise and so I leave it to the reader to take the claims about God that follow in their own preferred mode.

Now, in turning to currently popular accounts of happiness, not all of them can make sense of the notion that God is happy. I think here, for example, of sensory hedonism, according to which our happiness is a matter of pleasant sensations. On the classical picture, of course, God does not have any sensations..$^{10}$ So sensory hedonism cannot make sense of the idea that God is happy. However, a wide array of popular accounts concerning the nature of happiness can make sense of the idea that God is happy and, indeed, all-happy. I show that this is so by briefly applying to God a variety of views taken from the following families of theories: desire satisfactionism, hedonism, objective list accounts, and hybrid accounts.

\section{I.a. The All-Satisfied God}

At its most general, desire satisfactionism holds that a person is happy or doing well to the extent to which their desires are satisfied. Usually, desire satisfactionism is further divided into two camps: on the one hand, there's the camp occupied by those who think that the relevant desires are a person's actual desires and, on the other hand, those who think that the relevant desires are the idealized desires of a person (e.g., the desires a person would have, if she had all the relevant facts, reasoned well, and formed those desires while in a rational state of mind). ${ }^{11}$ However, we needn't worry about the differences between those two camps here, since God's being omniscient and perfectly rational guarantees that God's actual desires and idealized desires could never come apart.

Now, of course, even on a classical theistic picture, God is supposed to have desires, at least in some sense. At the very least, God is supposed to be pro- some things and anti- others. Pro-our loving our neighbors. Anti-our being malicious. Pro-our finding our way to God. Anti-our rejecting God. So it seems that, at least in principle, sense can be made of God's having God's desires satisfied and so, if desire satisfactionism were the correct view about happiness, sense could be made of God's being happy.

We can also make sense of God's all-happiness on this picture, at least in principle. At the very least, sense can be made of it on versions of desire satisfactionism that treat the intensity of one's desires as crucially relevant to the degree of happiness that one enjoys-perhaps the clearest example is found in those who claim that "the intrinsic value for its subject of a

\footnotetext{
${ }^{10}$ In the Christian tradition, complications stemming from Jesus aside.

${ }^{11}$ For this sort of account of idealized desires, see, e.g., Harsanyi, "Morality and the Theory of Rational Behavior," 55.
} 
basic desire satisfaction = the intensity of the desire satisfied." 12 On such a view, in the first place, what it would take for God to be all-happy is God's having an infinitely strong or infinitely intense desire or pro-attitude towards something that, in fact, obtains. If this were the case, all else being equal, God would be infinitely happy.

In the tradition of classical theism, God does have precisely such a desire or pro-attitude towards one and only one thing, namely, God's self. God infinitely loves, desires, and is pro- God's self. Although this may sound strange or even objectionably narcissistic, the idea behind it is simple: God loves, desires, and is pro- things precisely in keeping with how good they are. God is infinitely good. And so God loves, desires, and is pro- God's self infinitely. Since God is always satisfying God's infinite desire for God's self, God is by God's very nature always infinitely satisfied by God's self. If desire satisfactionism is true, then-all else being equal, at least - a being that is infinitely satisfied is infinitely happy. So, if desire satisfactionism is true, all else being equal, God is infinitely happy.

This, I take it, is enough to show that, in principle, desire satisfactionism can make sense of the idea that God is infinitely happy or all-happy. However, one might worry that this explanation leaves open the unsavory possibility that, in fact, God could fail to be infinitely happy or all-happy. ${ }^{13}$ After all, perhaps all else isn't equal. For example, perhaps God has an infinitely strong desire for something that doesn't obtain competing with God's infinite self-satisfaction and so God is not infinitely happy. Or perhaps God has an infinite number of desires for things that don't obtain and so God is not infinitely happy. If God is thought to be infinitely happy or all-happy necessarily, something must rule out these possibilities.

Given other theses that make up or surround the constellation of classical theism, both of these possibilities can be ruled out. In the first case, this is ruled out as follows. If God were to have an infinitely strong desire for something that doesn't obtain, that desire would either be a desire that something infinitely good obtain, which doesn't obtain, or a desire that something infinitely bad wouldn't obtain, which does obtain. These are the only two possibilities because, as noted above, the intensities of God's desires are pegged to how good or how bad things actually are. Now, in the tradition of classical theism at least, it is impossible for there to be anything infinitely good other than God because the only things that exist other than God are created things and even the best of creatures can only

\footnotetext{
${ }^{12}$ See, for example, Heathwood, "The Problem of Defective Desires," 489. Other possible differences between versions seem less relevant for present purposes, such as actualist versus idealist versions, as noted in the main text, and summative versus global versions (i.e., versions on which how well a life is going depends on the summing of all one's satisfactions and frustrations versus a version on which desires about one's whole life or its main features count for more). In the latter case, it doesn't seem relevant because God's being infinitely pro- God's self is, in the divine life, the desire that concerns by far its most central feature.
}

${ }^{13}$ I owe this worry to Mark Murphy. 
be finitely good. ${ }^{14}$ Furthermore, it is impossible for there to be anything infinitely bad because, obviously, God is not infinitely bad and even the worst of creatures can only be finitely bad.

However, that doesn't rule out the possibility that God might have an infinite number of desires for finitely good things to obtain that don't obtain or an infinite number of desires that a variety of bad things wouldn't obtain, which do obtain. Now, either of these possibilities or some combination of them would require the more general possibility of there being an actually infinite number of things in a world created by God. After all, since all God's pro- and con-attitudes towards finitely good and bad things are in keeping with their goodness and badness, God is only finitely pro- and finitely con- every particular finite good and bad respectively. So, if this is to create a problem, it must be the case that God desires the existence of an infinite number of potential finite good things or the non-existence of an infinite number of actual finite bad things (or an infinite combination of these). These possibilities require God's at least desiring, if not creating, an actually infinite number of finite things. However, the possibility of God's desiring the existence of an actually infinite number of things is something that classical theists, at least, deny. ${ }^{15}$ Different reasons are given that show God could desire no such thing, such as that a well-ordered world-and so the sort of world God would desire to create-could not include an actually infinite number of things. ${ }^{16}$ So, if classical theists are correct, a necessary condition for God's having infinitely many unsatisfied desires concerning finite things could never obtain: God's desiring the existence of an actually infinite number of things.

If all of this is right, then, even in principle, the God of classical theism could not have an unsatisfied infinitely intense desire or an infinite number of unsatisfied desires with finite intensities. When taken together with God's infinitely intense desire for God's self, it seems that on the versions of desire satisfactionism under consideration at least, God must, by God's very nature, be infinitely happy or all-happy.

\section{I.b. The All-Joyful God}

As I noted above, not all varieties of hedonism can make sense of God's happiness, let alone God's all-happiness. However, hedonistic views that treat the relevant sort of pleasure or delight as attitudinal, rather than a matter of sensation, can-at least in principle-account both for God's happiness and God's all-happiness. An attitudinal variety of hedonism maintains that the sort of pleasure or delight relevant to happiness or wellbeing is a matter of a pro-attitude that need not involve any sensations -it is the sort of pro-attitude or being pleased that one might have waking up

\footnotetext{
${ }^{14}$ For, e.g., Aquinas's explanation as to why nothing but God can be essentially, unqualifiedly infinite, see, e.g., Summa Theologiae Ia 7, 2.

${ }^{15}$ See, e.g., Aquinas's Summa Theologiae Ia 7, 4.

${ }^{16}$ See, e.g., Aquinas's Summa Theologiae Ia 7, 4 and Ia 47, 3.
} 
from a successful surgery completely numbed and without any pleasant sensations. ${ }^{17}$

On a classical theistic picture, again, God is thought to have these sorts of pro-attitudes as well as the delights or enjoyments associated with their satisfaction. Interestingly, one sees some classical theists invoking these sorts of divine delights precisely in the context of God's happiness. Thomas Aquinas, for example, claims that "God Himself would not be happy, if God did not know and love God's self, since then God would not delight in God's self, which is required for happiness."18 So, if attitudinal hedonism were true, in principle, nothing stands in the way of God's being happy.

So too, nothing stands in the way of God's being all-happy. After all, God does not delight in or enjoy God's self just a little bit. God enjoys God's self in keeping with God's infinite goodness and so God's enjoyment of God's self is infinite. ${ }^{19}$ (And, we might add, there is no thing and no collection of things towards which God has an infinitely strong con-attitude, for the reasons outlined above-a point I will refrain from rehearsing in subsequent sections.) So, if attitudinal hedonism is true, God is infinitely happy.

\section{I.c. The All-Good-Possessing God}

At their most general, objective list theories claim that there are a number of discrete items that in themselves make one's life better or make one happier. In the case of human beings, some popular items to include are life, knowledge, friendship, aesthetic experience, and appropriately taken pleasure. ${ }^{20}$ The members of such a list may be generated by appeal to some underlying principle-the most popular being that items on the list in some sense perfect us as human beings. Or they may be generated simply by appeal to reflective judgment.

Perhaps it is true that, as in our case, God's life, knowledge, appropriately taken pleasure, and so on are the very things that constitute God's happiness. Thankfully, here we can avoid such contentious matters as, say, how we should think of God's form of life or what reflective judgment suggests is good in itself for God. The classical tradition makes it possible to bypass such difficult questions. After all, according to that tradition, God is Goodness Itself, the good of every good thing, infinitely good in God's self. As a result, God by God's very nature is in possession of infinite objective goodness. So, if happiness is a matter of the possession of what is objectively good, then God is and could not fail to be happy and, indeed, infinitely happy.

${ }^{17}$ Feldman (Pleasure and the Good Life) defends a version of this view.

${ }^{18}$ Aquinas, De Veritate, 29, 1.

${ }^{19}$ For an example of this in the tradition, see, e.g., Aquinas, Summa Theologiae IIaIlae 28, 3.

${ }^{20}$ See, e.g., Finnis, Natural Law and Natural Rights; Parfit, Reasons and Persons; Fletcher, "A Fresh Start for the Objective List Theory of Well-Being"; and Murphy, Natural Law and Practical Rationality. 


\section{I.d. The All-Good-Enjoying God}

In standard versions, hybrid theories of happiness hold that happiness always involves two interlocking aspects. The first concerns the objective goodness of what one is doing or of some element involved in what one is doing, such as the object of one's attention. The second concerns one's feelings or attitudes towards what one is doing. For example, Robert Adams defends a hybrid theory according to which well-being, or happiness in our sense, is a matter of enjoying (an attitudinal response to) what is excellent (a sort of objective goodness). ${ }^{21}$

So long as a hybrid theory takes the relevant sort of feeling or attitude to be akin to a pro-attitude, hybrid theories can also make good sense of God's happiness. After all, as we've seen, on the classical picture, God is thought to be infinitely objectively good. Furthermore, God is thought to be engaged in an infinitely objectively good activity with God as its infinitely good object. When paired with God's infinite enjoyment of God's self, it seems that no matter how the interlocking aspects are supposed to relate, it will turn out that God is not only happy, but infinitely so.

\section{Our share in God's happiness}

It should now be clear that, when taken in conjunction with other claims defended by classical theists, we can make sense of God's all-happiness on a wide array of popular views concerning the general nature of happiness. What may not yet be clear is how or in what sense God might share God's happiness with human beings on these proposals. At the most general level, of course, if any one of these general accounts is true, it applies to human beings and to God and so our happiness is similar to God's in that sense. However, in the tradition, it is clear that the human share in divine happiness is supposed to go much further than that.

In particular, human beings are thought, with God's help, to be capable of sharing the very stuff of God's happiness. Indeed, in the classical tradition, it is commonly thought that God makes it possible for the truly fortunate to engage in and enjoy the same sort of activity that explains God's own happiness. That divine activity, as I've hinted at above, involves multiple elements. First, it involves God's profoundly knowing and being deeply in touch, as it were, with God's infinitely good self. Second, it involves God's intensely enjoying God's self. Finally and unnoted above, it involves God's engaging in that activity from eternity. In the human case, it is thought that God can give us something similar to each of these elements. In particular, it is thought that God makes it possible for us to know God profoundly and to be deeply in touch with God's infinitely good self; to enjoy God intensely; and to do so without end. This sort of happiness is supposed to be the destiny of the saints in heaven. It is clear why one might describe such a situation as God's sharing God's happiness

\footnotetext{
${ }^{21}$ Adams, Finite and Infinite Goods, 83-101.
} 
with us, whether-fundamentally and strictly speaking - that happiness is ultimately a matter of our being satisfied by God's goodness, our enjoying God through that activity, our possessing all that is good in God, or some hybridization of the goodness and enjoyment we experience. ${ }^{22}$

Now, of course, the share in divine happiness is not total on the classical view. So it is also important to note how the various accounts of happiness in general can accommodate a merely partial sharing of divine happiness. On the side of views that stress the importance of objective goods to happiness, the objectively good activities of human beings, even the activity whereby they are joined to God in intimate knowledge, can only be finitely good-never infinitely good. This is so because the activity of any finite being will itself be finite (even if it has something infinitely good for an object) and so the activities of finite beings will always be less than infinitely good. This brings home that in God's own happiness it must be the case that the manner in which God knows and appreciates God's self is, in an important sense, the more important element for securing God's infinite happiness. It is the infinitely good character of the manner of God's activity, rather than the object's infinite goodness, that secures the result that, with respect to the objective goodness of the activity, divine happiness is infinitely greater than heavenly human happiness. To make sense of this, you might think of the objective goodness of the activity or of the objective goodness reachable through the activity as somewhat like a quantity of juice squeezed from an orange. In the case of God and the saints in heaven, the orange in question contains an infinite amount of juice. The difference between God and the saints is that the saints, even when strengthened by God, can only ever remove a finite amount of juice, whereas God is able to extract an infinite amount.

In the case of views stressing the importance of having one's desires satisfied, of enjoyment, or of having some sort of pro-attitude towards things that actually obtain, here too there is an important difference between God's happiness and our own, even in the special case of heaven. After all, because of their finite wills, human beings cannot desire God infinitely, they cannot enjoy God infinitely, they cannot have any infinitely strong pro-attitude towards God. Here too, God's happiness, as including infinite desire satisfaction or infinite enjoyment or some infinite pro-attitude, lies infinitely beyond human reach.

Finally, although human beings can be raised to indefinite life by God, they cannot be elevated to life in the eternal now. One might think that this also matters when it comes to how happy we are in comparison to God. To see why, for starters, it is important to remember that, as it is thought of in the classical theistic tradition, following Boethius, "Eternity is the complete possession all at once of illimitable life." ${ }^{23}$ On this understanding

\footnotetext{
${ }^{22}$ It is also thought to be the destiny of the good angels.

${ }^{23}$ Boethius, The Consolation of Philosophy, V, 6. Aquinas quotes this definition, e.g., at Summa Theologiae Ia 10, 1. For a contemporary discussion of this understanding of eternity, see Stump and Kretzmann, "Eternity," 429-458.
} 
of eternity, an eternal being exists outside of time and without any succession of past, present, and future, but-instead-is, as it were, present to all of its existence at once. In thinking about what difference existing in this sort of higher temporal mode might make to happiness, it might be helpful to reflect on a character existing in a temporal mode far short of eternity, but whose existence is more like that of an eternal being than our own. Imagine, then, St. Longinus, a human saint in heaven. Say that at every particular moment in heaven, St. Longinus is extremely happy with precisely what he has at that moment. ${ }^{24}$ Now, take ten consecutive heavenly moments. ${ }^{25}$ Suppose that, through divine intervention, St. Longinus could be made to experience those ten consecutive moments as a single moment. It seems that St. Longinus would be happier in that single concentrated moment than he would in any of the ten separated moments on its own. ${ }^{26}$ Eternity might elevate happiness similarly-by, as it were, combining every happy "moment" into a super-concentrated, complete possession of all that is happiness-conducive all at once in an illimitable eternal now.

No matter which view about happiness in general one prefers, then, as the classical theistic tradition requires, there is a way to make sense both of human sharing in divine happiness and divine happiness's infinitely outstripping even the most divine human happiness.

\section{The Subjective Problem of Evil}

In the first two sections, I have argued that an array of accounts concerning the general nature of happiness are capable of explaining what the tradition of classical theism demands-most importantly, why God should count as all-happy. However, even if I am correct about this, the question remains: should we retain the classical theist's belief that God is all-happy? It seems to me that the best reason to doubt that God has this purported attribute is what I call the "Subjective Problem of Evil." To motivate the problem, I begin with an extreme case of a kind of experience we are all familiar with: watching those we care about suffer.

At fourteen months, Andrew was diagnosed with leukemia. ${ }^{27}$ His parents, Esther and Dan, were, of course, deeply shaken by the news. Andrew

\footnotetext{
${ }^{24}$ I say "St. Longinus is extremely happy with precisely what he has at that moment" to make it clear that in this case the happiness does not depend in any way on succession or the passage of time, which-I take it-is the classical view of heaven.

${ }^{25}$ There are, of course, puzzles here about whether moments of time can truly exist side by side. I leave all such puzzles aside because the point that I am making could be restated no matter how one thinks of the division of time.

${ }^{26}$ I make no claims about whether such a moment would be ten times as good, as might be suggested by a simple additive picture, or whether such a moment would be better, but not ten times better, as might be suggested by some non-additive picture. For present purposes, all that matters is that such a concentrated moment, as it were, would be better to some extent for Longinus than one of the ten non-concentrated moments.

${ }^{27}$ All facts and quotations about Andrew's case were taken from Thernstrom, "When Do you Give Up on Treating a Child with Cancer?"
} 
underwent treatment, but the cancer returned. With Andrew's death all but certain, Esther wrote, "I can't think of anything more painful than spending time with your precious baby knowing that he is going to die soon." Eventually, Esther and Dan decided that enough was enough. They chose to cease treatment. In time, Andrew's cancer became very painful for him; he would moan or scream whenever he was awake. "It was unbearable for him and for us," Esther said.

It is deeply painful to watch those we truly care about suffer. And, as a result, watching those we truly care about suffer has a profound effect on our happiness. Esther and Dan, for example, described their lives before Andrew's cancer as "charmed." But, while waiting for Andrew's death, in responding to friends urging them to enjoy every moment, Esther would reply, "No, this is hell, and it sucks. He is still going to die, so there is nothing joyous about this time."

That watching those we care about suffer can greatly affect our happiness is no great surprise. And, indeed, it seems that there is something right about this. If we could see those we care about suffering and continue on as happy as before, there would be something deeply, morally troubling about that. It seems that only someone callous to the suffering of others could be so unaffected by it. Indeed, how could one be a good person and be as happy as before when calamity strikes those one cares about? So Dan and Esther's being less happy as their son suffers through treatment is not a sign of some weakness of character. Rather, it would be a sign of a weakness in their character if they went on as happy as before.

With this in mind, in turning to God, we seem to have a problem. Many people in the world for whom God cares are suffering. ${ }^{28}$ Now, either God's happiness is affected by that suffering or God's happiness is not affected by that suffering. ${ }^{29}$ If God's happiness is affected by it, then God is not allhappy. If God's happiness is not affected by that suffering, then God is not all-good. So, either God is not all-happy or God is not all-good. But, surely, God is all-good. Therefore, God is not all-happy. This is the Subjective Problem of Evil. As I noted at the outset, this problem is independent of the Problem of Evil. What is at issue here is God's subjective response to a world that includes evil, rather than God's objective, (in)active response to various evils. Even if there were a morally sufficient reason for God's

\footnotetext{
${ }^{28}$ Obviously, assuming that God exists.

${ }^{29}$ Of course, I don't mean to imply here that at one time God's happiness is $\mathrm{x}$ and at another God's happiness is y. This is intended as a counterfactual comparison from the perspective of eternity, as it were.

It is also worth noting here that I am assuming something that, e.g., Eleonore Stump has argued for, namely, that an unchanging God in the eternal now can be in reciprocal relationships with beings existing in time-relationships in which God is, in some sense, responsive to those beings existing in time. (See Stump, The God of the Bible and the God of the Philosophers.)

Finally, it is worth noting that I am assuming that all these general accounts of happiness, including all adequate objective list accounts of happiness (understood, again, as concerning how well one's life is going), will be able to explain what seems obvious: that my life goes worse when those I care about are suffering.
} 
allowance of each and every evil that occurs, the Subjective Problem of Evil would still need to be dealt with.

Of course, one might think that we should simply respond to this "problem" by denying that it is a genuine problem..$^{30}$ No, God isn't allhappy. What's the big deal? This sort of indifference cannot be shared by those hoping to retain the classical conception of God. So too those hoping to afford to divine happiness its traditional pride of place in explaining both human existence and human destiny may also have misgivings about giving up on God's all-happiness so readily. ${ }^{31}$ In the remainder of this section, I will try to show that one need not give up on all-happiness on the basis of the Subjective Problem of Evil. Before putting forward my preferred response to this problem, I consider a pair of apparently promising responses that I believe fail.

The first such response is built around an important difference between human beings and God: as all-powerful, God -in one sense or other-gets everything that God wants. Perhaps God gets exactly what God wants or, at the very least, it seems that nothing happens in the world without divine permission. Not so in the human case. And what makes a decrease of happiness the appropriate response in the human case-namely, that we aren't getting what we want-doesn't arise in the case of God. Thus, God's happiness should not be affected by suffering in the world.

It seems to me that this response fails: what makes a decrease of happiness the appropriate response in the human case is still present in the case of God. Unlike human beings, God may get what God wants. However, it is still a sign of moral imperfection to be unaffected by the suffering of others, even in cases in which one has a morally sufficient reason to cause someone else to suffer or to allow them to suffer. For example, Dan and Esther surely had a morally sufficient reason to have Andrew put through painful treatments, but it would certainly be a sign of moral imperfection in Dan and Esther if they were unmoved by Andrew's suffering. So noting that God gets what God wants in the allowing-sense does nothing to help us avoid the Subjective Problem of Evil. And, furthermore, if God's "getting what God wants" is taken to mean not only that God allows suffering in the world but causally determines it and is unmoved by that suffering, God comes off still worse (or, at the very least, no better) from a moral point of view.

The second apparently promising response, which I also believe ultimately fails, draws from another potentially relevant difference between us and God: God knows that all shall be well in the end, whereas, e.g., Dan and Esther are not in a position to know whether Andrew's suffering will produce any good effects. Since God knows that things work out in the

\footnotetext{
${ }^{30}$ Another way to deny that this is a problem would be to deny that God's perfection involves God's being concerned for creaturely well-being. (See, e.g., Murphy, God's Own Ethics.)

${ }^{31}$ Of course, one might be able to make due on this front with God's just being really, really happy and wanting to share that happiness with God's creatures.
} 
end, God's happiness should not, or at least need not, be affected by the suffering of those God cares about. However, this response also misses the mark. To see this, imagine that, given a round of painful chemo, leukemia like Andrew's disappears in 100 percent of cases. Now, it seems plausible to think that Dan and Esther should be happier in such a scenario than they should be if the survival rate were substantially lower. However, we would rightly think that Dan and Esther were morally deficient if they were unmoved by Andrew's suffering during the treatment, even if they knew that he would recover (which, in fact, he did!); his vomiting, his cries of pain, his exhaustion, his confusion about why this was happening would affect a good parent's level of happiness. So too it seems that, in the case of God, God should be affected as a result of the suffering of those God cares about, even though, from the perspective of eternity, God knows things will work out in the end.

These first two responses depend on ways in which God's power or knowledge differ from that of human beings. But it seems to me that the most promising response to the Subjective Problem of Evil involves thinking through the implications of God's all-happiness itself, however we conceive of the underlying nature of happiness in general. Recall that God's happiness is supposed to be infinite, whereas human happinesseven of the very best sort-is finite. It is well known that infinities have peculiar characteristics. One presently germane characteristic of infinities is that, no matter how large a finite value one subtracts from them, they remain infinities. ${ }^{32}$ This suggests a way forward that makes room for God's all-happiness and God's moral perfection, even in the face of a world that contains a great deal of suffering.

Although there is a great deal of suffering in the world, the amount of suffering is finite. This suggests that, if a morally good being cared about all the suffering in the world in keeping with its badness, the effect that all the world's suffering should have on one's happiness has a finite value as well. ${ }^{33}$ God's happiness has an infinite value. And so, even if God's happiness were to be affected in a way commensurate with all the suffering in the world throughout its history, God would still be infinitely happy. In this way, one can deny that it follows from the fact that God's happiness is affected by the suffering in the world that God is not all-happy. All-happiness is simply a matter of being infinitely happy. So God can be all-happy and God's happiness can be affected by the suffering in the world.

One might object to this response from two sides. First, one might argue that God's happiness is not really affected on this proposal and so God's moral character is still compromised. After all, God would be infinitely happy in a world without suffering and God would be infinitely happy

\footnotetext{
${ }^{32} \mathrm{I}$ use the language of numerical infinities to talk about God's happiness. I think the same relevant points follow if one speaks of God's happiness as analogous to other sorts of infinites, e.g., infinite spaces.

${ }^{33}$ In my view, attempting to give specific values is neither necessary, nor desirable.
} 
no matter how much finite suffering there might be in the world. Second, one might argue that God's happiness is, as it were, too affected on this proposal. After all, in conceding that God's happiness is affected even by a finite amount, the response thereby concedes that, as it were, bits of God's happiness are missing, which would be there in a world without suffering. But if bits of God's happiness are missing, then God should not be counted all-happy. One might think that this reveals that it's problematic to equate all-happiness and infinite happiness. I address these worries in turn.

Although it is true that God would be infinitely happy in a world without suffering and God would be infinitely happy no matter how much finite suffering there might be in the world, it is not true on this proposal that God's happiness isn't really affected by the suffering of God's creatures. To see this, consider a very special library. ${ }^{34}$ The library has an infinite number of books. In particular, it has a lovely infinite collection of red books and an equally lovely finite collection of green books. Now, say that the finite collection of green books is removed and destroyed. Would the library's collection be affected by this loss of books? One might think the answer is, "No." After all, there's an infinite number of books in the library's collection both before and after the green books are destroyed. However, it is clear that, despite the fact that the collection included an infinite number of books both before and after the green books were destroyed, the library's collection was really affected by this finite loss of books. After all, formerly, one could check out green books and now one can't. The case of the effect of suffering on God's happiness is relevantly similar. The happiness that God has in God's self is relevantly similar to the infinite collection of red books and whatever happiness God might have taken had God's creatures never suffered is relevantly similar to the finite collection of green books. Although it is true that God would be infinitely happy whether the world included suffering or not, it does not follow that God is unaffected by the suffering of God's creatures. In a world like ours that includes suffering, a part of God's happiness is missing, as it were. The suffering of creatures really does affect God's happiness, then.

But that seems to play right into the hands of the second objection. After all, this response concedes that bits of God's happiness are missing that wouldn't be if there were no suffering in the world. One might think that, surely, a being with missing bits of happiness isn't all-happy. And so, even though God may be infinitely happy in a world like ours, God should still not be counted all-happy. ${ }^{35}$ Or to put the point differently,

\footnotetext{
${ }^{34}$ I have drawn the example of an infinite library from conversation with Wes Morriston.

${ }^{35} \mathrm{An}$ anonymous reviewer pointed out that, given this concession, there is a sense in which it is clear that God does not count as all-happy, namely, insofar as one is thinking about all-happiness as a matter of being happy about everything without exception. In a world in which there is suffering, God is not happy about everything without exception. And so, if this is what all-happiness is, God is certainly not all-happy.

I think that this is right as far as it goes. However, I think that, as it is understood in the tradition, all-happiness must have to do with the magnitude of one's happiness, as it were, and not the content of one's happiness (i.e., it does not have to do with whether one
} 
one might think that this response reveals that it's problematic to equate all-happiness and infinite happiness.

Here, I think that it is important to notice that as an attribute all-happiness importantly differs from at least some other attributes classically ascribed to God, such as being all-powerful. ${ }^{36}$ In the case of being all-powerful, one might naturally suppose that there is an upper bound on how powerful a being could be-a bound imposed by logical possibility. God's power is not infinite - there is a limit. And in that context, it seems clear that, if one were to admit that God could be more powerful than God is, one should also admit that God is not all-powerful. For, at least in general, when there is a definite upper bound to some property, $X$, it makes good sense to equate being all- $X$ to reaching that definite upper bound. However, some attributes don't seem to have definite upper bounds. Happiness seems to be one such attribute-and it is, in fact, such an attribute, if any of the above accounts of happiness are correct. After all, whether it is a matter of desire-satisfaction, enjoyment, the possession of objective goods, or some hybrid of these, no matter how happy a being is, it seems that that being could always, in principle, be happier. That includes God. After all, it seems that, just as bits of God's happiness are missing due to the suffering of those God cares about, so too some bits of God's happiness are the result of the flourishing of those God cares about. ${ }^{37}$ So it seems that, in principle, God's infinite happiness could always have had more finite bits added to it by God's having created more flourishing creatures. At the very least, there is no logical contradiction involved in God's becoming happier and happier in this way without end. ${ }^{38}$ So, unlike in the case of being all-powerful in which it makes good sense to think that all-powerfulness requires being as powerful as it is logically possible to be, it does not make sense to think that all-happiness requires, say, being as happy as it is logically possible to be. After all, there is no such thing as "being as happy as it is logically possible to be" - conceiving of someone as still happier will never generate a contradiction. Now, if there is no upper bound on happiness, one cannot equate being all-happy to reaching a definite upper bound. What, then, is one to do? It seems to me reasonable in such cases to equate being all- $\mathrm{X}$ with being infinitely-X. And so, I think that it is best

is happy about everything). After all, otherwise, it seems, e.g., that, before the Fall, Adam might have been all-happy, since-we might suppose-Adam was happy about everything and unhappy about nothing. But, of course, all-happiness-like omnipotence-was meant to be reserved for God alone.

${ }^{36}$ Of course, some have shifted from talking about God's being all-powerful to God's being maximally powerful. For contemporary discussions of omnipotence, see, e.g., Flint and Freddoso, "Maximal Power," 81-113; Wierenga, The Nature of God; and Morriston, "Omnipotence and Necessary Moral Perfection: Are They Compatible?," 143-160.

${ }^{37}$ Here too, I don't mean to imply that at one time God's happiness is $\mathrm{x}$ and at another God's happiness is $y$. This is intended as a counterfactual comparison from the perspective of eternity, as it were.

${ }^{38}$ One implication of this is that, when it comes to God's happiness at least, there is no best possible world - there are just better and better worlds without end. 
to equate all-happiness with infinite happiness. And, in that case, the fact that God could have more bits of finite happiness, in one way or another, is compatible with God's being all-happy.

But one might think that this is the wrong conclusion to take from this line of argument. ${ }^{39}$ One might suggest instead that we should give up on the notion of all-happiness altogether and replace it with the notion of God's infinite happiness, since when it comes to happiness there is no all to be had. In my view, little substantive hangs on this substitution. Although it is perhaps less catchy, God's being infinitely happy is no less important an attribute than God's being all-happy. The motivations I gave for a serious philosophical investigation of divine happiness remain, whether God is thought to be all-happy or infinitely-happy. It is perhaps worth noting that the recognition of this quirk may have led some classical theists, like Aquinas, to be careful to call God only infinitely happy to begin with. ${ }^{40}$

However, one might still be dissatisfied with this response to the Subjective Problem of Evil. ${ }^{41}$ When first considering the effect of creaturely suffering on God's happiness, one might have thought that, in light of the concessions I made, creaturely suffering undermines God's all-happiness. That may have been a desirable result to some, since God's all-happiness being undermined lends weight to the idea that God's happiness is truly affected by creaturely suffering. But, if what is at issue is only infinite happiness, then it might seem that God's response to suffering has been cheapened to the point of being worthless. It might seem that infinite happiness, attained through God's self alone, has reduced to irrelevance any effects that the suffering of creatures might have on God.

In a sense, that is true. After all, for well-rehearsed reasons, creaturely concerns could never undermine God's infinite happiness. But, I take it, from the perspective of classical theism at least, this is a desirable result. It would be undue for God's well-being to depend so materially on creatures that God's well-being could be spoiled by them. Still, there is an important sense in which God's infinite happiness is actually affected by the suffering of creatures. As a result of the suffering of creatures, God's happiness is not the same as it otherwise would be. Due to the suffering of creatures, some bits of God's infinite happiness, as it were, are missing and missing precisely because of that suffering. But, since all suffering is only finitely bad, it could never have more than a finite effect on God's happiness. If one thinks more than that is necessary for a proper accounting of the effect that the suffering of creatures should have on God's happiness, perhaps what one ultimately finds objectionable is the classical theism that lies in the background. Classical theism, after all, is committed to making God virtually invulnerable. Now, although it is well worth thinking about whether one should embrace classical theism more generally, since this

\footnotetext{
${ }^{39}$ I owe this worry to Mark Murphy.

${ }^{40}$ See, e.g., Aquinas, Summa Contra Gentiles I 102, 6.

${ }^{41}$ I owe this worry to Mark Murphy.
} 
paper concerns how one might think about and defend God's happiness from within the classical theistic tradition, this worry can be set aside in the present context.

\section{Conclusion}

Classical theists have long held that God is happy in an especially exalted way. They have also called upon God's happiness at crucial moments in order to explain fundamental theological doctrines, such as the creation and destiny of human beings. This essay is an attempt to start to give divine happiness the serious philosophical treatment it deserves. That treatment began with a variety of accounts concerning the general nature of happiness, all of which can make sense of God's all-happiness. I have argued that, given any of these understandings of happiness and traits classically ascribed to God, God turns out to infinitely happy. I further noted that all of these general accounts of happiness can undergird the traditional Christian claim that God created us to share in God's happiness; the functional role of divine happiness is preserved. Finally, I raised and attempted to address what I take to be the central difficulty associated with ascribing all-happiness to God-the Subjective Problem of Evil. It seems to me that the problem can be addressed by attending in a sustained way to the implications of God's being infinitely happy. So nothing stands in the way of the All-(or at least Infinitely-) Happy God. ${ }^{42}$

San José State University

\section{References}

Adams, Robert. 1999. Finite and Infinite Goods: A Framework for Ethics (Oxford University Press).

Anselm. 1968. Proslogion. In Opera Omnia, edited by F. S. Schmitt (Frommann).

Aquinas, Thomas. 1882. Opera Omnia. Edited by the Leonine Commission.

Aquinas, Thomas. 1961. Summa Contra Gentiles. Edited by P. Marc, C. Pera, and P. Caramello (Marietti).

Aquinas, Thomas. 1888-1906. Summa Theologiae. Edited by the Leonine Commission (Ex Typographia Polyglotta S. C. de Propaganda Fide).

Aquinas, Thomas. 1970-1976. Quaestiones Disputatae De Veritate. Edited by the Leonine Commission.

Aquinas, Thomas. 1982. Quaestiones Disputatae De Malo. Edited by the Leonine Commission (J. Vrin).

\footnotetext{
${ }^{42}$ First, I would like to thank the Classical Theism Project and its Directors, Gloria Frost and Tim Pawl, for providing support that made the development of this paper possible. I would also like to thank Bob Pasnau and Dan Lowe for feedback on an earlier version of this paper. I am also grateful for the help I've received from two anonymous referees from Faith and Philosophy and from its editor, Mark Murphy.
} 
Bergmann, Michael and Jeffrey E. Brower. 2006. "A Theistic Argument against Platonism (and in Support of Truthmakers and Divine Simplicity)." Oxford Studies in Metaphysics 2: 357-386. https:/global.oup.com/academic/product/ oxford-studies-in-metaphysics-9780199290581.

Boethius. 1934. Consolatio Philosophiae. In Corpus Scriptorum Ecclesiasticorum Latinorum, Vol. 67, edited by W. Weinberger (Akademie der Wissenschaften in Wien).

Catholic Church. 2012. Catechism of the Catholic Church, 2nd ed. (Libreria Editrice Vaticana).

Darwall, Stephen. 2002. Welfare and Rational Care (Princeton University Press). https://doi.org/10.1515/9781400825325

Feldman, Fred. 2006. Pleasure and the Good Life: Concerning the Nature, Varieties, and Plausibility of Hedonism (Clarendon Press). https://doi.org/10.1007/s11098-006-9039-y

Feldman, Fred. 2012. What is This Thing Called Happiness? (Oxford University Press).

Finnis, John. 1980. Natural Law and Natural Rights (Clarendon Press).

Fletcher, Guy. 2013. "A Fresh Start for the Objective List Theory of Well-Being." Utilitas 25: 206-220. https://doi.org/10.1017/S0953820812000453

Flint, Thomas, and Alfred Freddoso. 1983. "Maximal Power." In The Existence and Nature of God, edited by Alfred Freddoso (University of Notre Dame Press), 81-113.

Harsanyi, John C. 1982. "Morality and the Theory of Rational Behavior." In Utilitarianism and Beyond, edited by Amartya Sen and Bernard Williams (Cambridge University Press), 39-62.

Haybron, Daniel. 2008. The Pursuit of Unhappiness: The Elusive Psychology of WellBeing (Oxford University Press).

Heathwood, Chris. 2005. "The Problem of Defective Desires." Australasian Journal of Philosophy 83: 487-504. https://doi.org/10.1080/00048400500338690

Kretzmann, Norman, and Eleonore Stump. 1981. "Eternity.” The Journal of Philosophy 78: 429-458. https://doi.org/10.2307/2026047

Morriston, Wes. 2001. “Omnipotence and Necessary Moral Perfection: Are They Compatible?" Religious Studies 37: 143-160. https://doi.org/10.1017/S003441250100556X

Mullins R. T. 2013. "Simply Impossible: A Case Against Divine Simplicity." Journal of Reformed Theology 7: 181-203. https://doi.org/10.1163/15697312-12341294.

Murphy, Mark C. 2001. Natural Law and Practical Rationality (Cambridge University Press).

Murphy, Mark C. 2017. God's Own Ethics: Norms of Divine Agency and the Argument from Evil (Oxford University Press).

Parfit, Derek. 1984. Reasons and Persons (Clarendon).

Rawls, John. 1999. A Theory of Justice: Revised Edition (Belknap Press).

Stump, Eleonore. 2016. The God of the Bible and the God of the Philosophers (Marquette University Press).

Thernstrom, Melanie. 2016. “When Do you Give Up on Treating a Child with Cancer?" New York Times, May 12, http://www.nytimes.com/2016/05/15/magazine/ childhood-cancer-treatment.html?_r=0. 
Wierenga, Edward. 1989. The Nature of God (Cornell University Press).

Wolf, Susan. 2010. Meaning in Life and Why It Matters (Princeton University Press). https://doi.org/10.1515/9781400834594

Woodard, Christopher. 2015. “Hybrid Theories." In The Routledge Handbook of Philosophy of Well-Being, edited by Guy Fletcher (Routledge), 161-174.

Yandell, Keith. 2009. "How Many Times Does Three Go Into One." In Philosophical and Theological Essays on the Trinity, edited by Thomas McCall and Michael Rea (Oxford University Press), 151-169.

https://doi.org/10.1093/acprof:oso/9780199216215.003.0009 